\title{
"Tracking Papyrus and Parchment Paths": A New International Project on Coptic Literature
}

\author{
Paola Buzi, Julian Bogdani, Nathan Carlig, Maria Chiara Giorda, Agostino Soldati
}

The purpose of the new project presented in these pages is to offer an innovative approach to the study of the evolution of Coptic literature and, more specifically, to the corpus of writings produced in Egypt between the third and the late eleventh centuries, and expressed in the different dialects of the Coptic language. Its aim is to provide a new perspective on the cultural landscape of Christian Egypt by interweaving literary, historical, codicological and archaeological data, and producing a series of scholarly tools, till now unavailable, in a digital environment, including an archaeological Atlas of late antique and early mediaeval Coptic literature that will be searchable at different chronological, regional and thematic levels.

As part of the above-described research activities and goals, a complete catalogue of the Coptic papyrus codices preserved in the Museo Egizio will be produced, as well as an edition of their titles and scribal subscriptions. The fragmentary codices in question, purchased in Egypt by Bernardino Drovetti in the 1820s, are a unique example of an entire well-preserved late antique institutional library - very likely originally belonging to the cathedral of This/Thinis - reflecting the literary tastes and dogmatic orientations before what can be defined as the ninth-century Coptic book revolution, which significantly changed bookmaking in Christian Egypt. The library of Thi(ni)s is a crucial and transitional instance in the history of Coptic books, which saw on the one hand the creation of new codicological and palaeographical features and on the other the progressive emergence of multiple-text codices.

$$
\begin{aligned}
& \text { الغرض من الدر اسة الجديدة التى بتم عرضها فى هذا البحث هو تقديم نهج مبتكر آ لدراسة تطور الآدب القبطى، }
\end{aligned}
$$

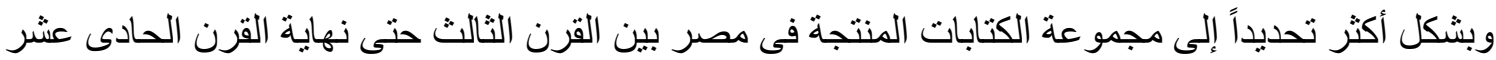

$$
\begin{aligned}
& \text { و التى تم التعبير عنها فى لهجات مختلفة للغة القبطية. هدفها هو توفير منظور جديد للمشهد الثقافى فى مصر } \\
& \text { المسيحية من خلال تداخل البيانات الأدبية والتاريخية و الآثرية و الكوديكولوجية (در اسة الكتب القديمة)، و إنتاج } \\
& \text { سلسة من الأدوات العلمية حتى الآن غير منوفرة فى بيئة رقمية من خلال أطلس آثرى لأدب أواخر العصور } \\
& \text { القديمة والأدب القبطى من العصور الوسطى، و القابلة للبحث علي مختلف المستويات الزمنية و الإقليمبة } \\
& \text { و الموضو عية. }
\end{aligned}
$$

وكجز ع من الأنشطة والأهداف البحثية الموصوفة أعلاه سبتم التحقق من فهرس كامل لمخطوطات البردى القبطية المحفوظة بالمتحف المصرى بتورينو، بالإضافة إلى نسخة من عناوينها ومعلومات عن أسم الكاتب ودار النشر و التاريخ الذى نشرت فية .

نحن بصدد در اسة سبعة عشر مخطوطة مجز أة والتى تم شر اؤها من مصر بو اسطة برناردينو دروفيتى عام 1820م، و هى تعد مثنال فريد للحفظ الجيد الكامل لمجموعة من الكتب التى تعود إلى أواخر العصور القديمة، من المحتمل أن تنتمى فى الأصل إلى كاتدر ائية زيس والتى تعكس الأذو اق الأدبية و التوجهات العقائدية قبل ما يمكن إنى تعريفة بأنة القرن التاسع للثورة الكتابية و التى غيرَت بشكل كبير صناعة الكتب فى مصر المسيحية، فإن مكتبة زيس هى مثنال حاسم و إنتقالى فى تأريخ الكتب القبطية التى شهدت من جهة خلق ملامح جديدة كوديكولوجية ورقمية وحياتية ومن جهة أخرى ظهور تدريجى للنصوص المركبة التعددية. 


\section{Preamble: The evolution and role of Coptic literature in early Egyptian Christianity}

P.B. ${ }^{1}$

After three centuries of Ptolemaic rule, Roman Egypt appeared strongly marked by multiethnicity, multiculturality, and multilingualism. While Egyptian (Demotic) continued to be used as the current language, Greek was the main linguistic tool for what concerned literary production and all the bureaucratic aspects related to official affairs, while Latin had a marginal role, being the language of the cives romani (mainly soldiers) and law.

In such a complex cultural, religious and linguistic situation, despite the resistance of the traditional cults, Christianity slowly but progressively emerged. Although there are no concrete elements to confirm the traditional attribution of the evangelization of Egypt to the apostle Mark, it is very likely that the new religion reached the Egyptian Mediterranean coast quite early and that it was perceived early on as a new and potentially strong cohesive factor. The role of Alexandria, the cultured city par excellence, with its renowned philosophical circles and institutions, was certainly determinant in this respect. ${ }^{2}$

From the end of the second century onward, the cultural richness of Christian Egypt was further increased by the emergence of a "new", partly artificial language that represents the last phase of the exceptionally long Egyptian linguistic tradition. ${ }^{3}$ This new phase of the Egyptian language, characterized by a variety of regional dialects, which was only later destined to become also vernacular, was Coptic.

In the framework of a Church in construction, it is not surprising that the first phase of the literary production in Coptic consisted of the systematic translation, from Greek, of biblical works (thirdfourth centuries). Egyptian Christianity, however, was not a homogeneous reality in the first centuries. Besides translations of Old and New Testament works, therefore, we also find philosophical treatises that appear to have been produced within religious groups whose doctrinal choices and exegetical practices were rather different from those of the communities representing the "orthodox" Christianity. This is the case, for instance, of the "Gnostic" and, more in general, heterodox texts found in Nağ Hammādī and the Manichaean texts uncovered in Madinat Māḍī and Kellis.

At the same time, however, other groups of people, belonging to a more traditional Christian milieu, were responsible for the translation of a large number of Greek homilies. This process, destined to last a long time, initially focused mainly on the production of the Cappadocian Fathers and of John Chrysostom. Consequently, Coptic literature often preserves Greek works that have been lost in their original language. ${ }^{4}$

Between the fourth and fifth centuries, Coptic Egypt was ready for a decisive step: the creation of an original literature, an enterprise for which the role of monasticism - one of the most significant cultural phenomena in Christian Egypt - was decisive. After the pioneering experience of Antony, the celebration of a genuine, "national" religiosity embodied by figures of Egyptian anchorites, whose greatness lay in the choice of a modest life, became the fulcrum of several other texts produced at the same time or immediately Pachomius' foundation of the first coenobitic monastery, whose life was regulated by a set of rules. The apophthegmata patrum - i.e., sentences attributed to the desert fathers - present several other figures of monks as models of genuine Egyptian Christianity, fixing an ideal and stereotyped image of monastic life.

With the figure of Shenoute, archimandrite of a confederation of monasteries coordinated by the so-called White Monastery, located not far from $\mathrm{Pa}-$ nopolis, Coptic finally rose to the role of the literary language of Christian Egypt. ${ }^{5}$ To the deliberately "anti-literary" stance of Pachomius and his followers, expressed by their use of the genres of letters and rules, Shenoute opposed a complete adhesion to the genres of Greek and Alexandrian literature, becoming the author of homilies whose contents are extremely effective and engaging. In Shenoute's production, alongside works written for the monastic community, there was also room for texts inspired by the author's aversion for the plurality of heterodox currents, such as Origenism, Melitianism, Manichaeism. Shenoute's vehemence in his homilies reveals that Christian Egypt was going through one of its most critical moments as far as doctrinal disputes are concerned. ${ }^{6}$ 
The fifth century saw the most significant religious upheavals, culminating with the Council of Chalcedon (451), which over time determined a fracture, both dogmatic and hierarchical, with most of the other Churches. The Coptic literary tradition thus became slowly but more and more evidently detached from the Greek "international" one. ${ }^{7}$ This was when the Coptic Church was truly born. After the extremely confused hierarchical and religious situation that immediately followed the Council, the separation of Egypt from the positions of the "Great Church" increased the Copts' pride in their identity, and literature was not long in supporting this orientation, above all by means of a historiographic production. Between the fifth and sixth centuries, both original literary production and translation of homiletic texts went on. At the same time, an interest in hagiographic texts - individual or, more often, collected in cycles - began to rise in Coptic literature, which had reached its full-fledged linguistic potential. These texts inherited the general characteristics of similar works previously translated from Greek, but now mainly featured local martyrs as their main characters. The most striking result of such a literary process, which was to continue at least until the eighth century, are the so-called "epical martyrdoms" - literary texts that strongly contributed to creating a Coptic identity through the memory of the violence suffered by the faithful. These text are all characterized by the same elements: an evil emperor (usually Diocletian), an edict of persecution, a cruel judge, a long series of punishments inflicted on the martyr, and an equally long series of miracles performed by him before and after his death. ${ }^{8}$

The sixth century, however, was also the era of the cultural circle gathered around the figure of the patriarch Damian, who was responsible for the reorganization of the Egyptian Church after the Chalcedonian schism. Beyond the individual personalities of the authors, the literary production of this period - destined to be used at the most important moments of aggregation (masses, festivals, celebrations of saints and martyrs) of the Egyptian ekklesía - had two main aims: firstly to preserve those Greek patristic texts that were compatible with the anti-Chalcedonian choice of Coptic Egypt, and secondly to produce new works that would serve the liturgical purposes of a Church that was now completely independent.

The Arab conquest did not seem to affect Coptic literary production, which appears to be, at least at this early stage, still quite lively. It was, however, inevitably, a precarious balance. The last phase of Christian Egyptian literature written in Coptic was characterized by the selection and rearrangement - sometimes under new titles - of those texts that appeared still useful for liturgical purposes and for the promotion of the local religious identity. The evident result of this work is the Alexandrian Synaxarium, preserved in Arabic and consisting of a selection of hundreds of brief hagiographic texts arranged according to the liturgical calendar. The Arabic language, however, became increasingly intrusive, evolving from a bureaucratic and legislative tool into the new and exclusive language of Egypt. From the early eleventh century onward, a new phase began for Coptic literature, namely, its translation into Arabic. ${ }^{9}$ Coptic-Arabic literature was thus born. ${ }^{10}$

\section{Purpose of the project and expected results}

P.B.

The purpose of the new project presented in these pages - whose acronym is "PAThs" - is to offer an innovative approach to the study of the above-described evolution of Coptic literature and more specifically to the corpus of writings - almost exclusively of religious content - produced in Egypt between the third and the end of the eleventh centuries in the different dialects of the Coptic language. The aim is to provide a new perspective on the cultural landscape of Christian Egypt by interweaving literary, historical, codicological and archaeological data, and producing a range of so far unavailable digital scholarly tools, including an archaeological Atlas of late antique and early mediaeval Coptic literature that will be searchable at different chronological, regional and thematic levels. This Atlas is intended to illustrate the strong interconnection between intellectual and material production, on the one hand, and geographical provenance, on the other. In this respect, Christian Egypt represents a unique opportunity, since no other Mediterranean region has yielded such a rich archaeological and bibliological documentation. 
It is hardly necessary to emphasize the fact that Egypt can be regarded as one of the principal laboratories where what we define as "book" was gradually evolved and perfected. ${ }^{11}$ "PAThs" will study Coptic books as material artifacts (showing how the writing support, shape and layout change according to content and purpose), as intellectual products (that is as a selection and combination of texts: particular attention will be devoted to multiple-text codices), but also as ritual objects (for example as part of a "funerary kit", a sort of Christian Book of the Dead), yet always strictly relating them to their archaeological settings. Moreover, "PAThs" will try to establish and promote a shared terminology for Coptic codicology. ${ }^{12}$

In brief, by taking into account a large corpus of works, manuscripts and archaeological sites and interrelating them, "PAThs" ultimately aims to produce a new state-of-the-art of Coptic studies, in which literature will no longer be regarded as a cultural phenomenon independent of its material context, and which will go beyond the traditional narrow disciplinary subdivisions (especially in the fields of philology and archaeology) that have typified Coptic studies so far.

The ambitious purpose of the project is to provide a diachronic outline of the geography of Coptic literary production, which will be analyzed through an innovative and multidisciplinary approach, combining philology, codicology, history, archaeology and digital humanities, in order to explore the entire lifecycle of Coptic works, from production to dissemination and storage, in relation to the geographical contexts of origin of both the texts themselves and their writing supports.

By means of an analysis of philological aspects, dialects, style, content, scribal subscriptions, titles, and internal elements, Coptic texts will be related not only to the physical spaces where they were copied and disseminated but, more importantly, to the places where they were conceived, in order to reconstruct the identity of the cultural milieu (for instance a monastic community or an episcopal see) responsible for the creation of literary genres and specific works. This approach is particularly congenial for hagiographic and monastic literary production (for example cycles of martyrdoms, which represent an important part of Coptic literature), where ideolog- ical and devotional motifs may be extremely telling. The most visible product of the project will be the above-mentioned archaeological Atlas of late antique and early mediaeval Egypt. It will be interactive, in-depth, upgradable, ${ }^{13}$ and searchable at different chronological, regional and thematic levels. It will document, among other data:

- the places where Coptic manuscripts have been found and/or produced, and used, with a focus on monastic settlements, episcopal sees, tombs, and urban contexts;

- other works in combination with which a specific text was transmitted, in order to identify modes and ideologies in Coptic literary production, which were subject to changes (for example, the Vita Onuphrii was transmitted with different works in different periods), but also to the tastes of individual patrons;

- the plausible places where the works were conceived and created, with particular attention to monastic and hagiographic production, which provide more clues for such an investigation;

- the codicological features of the manuscripts (book format, writing support, ruling system, presence of a binding, etc.) and their development in relation to a specific period and a specific region;

- information related to the manuscript makers and related contexts (places where they practiced their trade, places where they obtained their writing supports, etc.);

- information concerning the copyists (family relationships, normal professions, times of execution). "PAThs" will integrate into its portal the just described archaeological Atlas of Coptic literature with a relational database composed of several "tables", all of them in keeping with the purpose of creating a concrete link between literary production and related geographical and archaeological context. The Atlas will include:

- A complete classification of Coptic literature, by means of the attribution of a Clavis Coptica (CC) entry to each work and each title (the latter often being created later than the work to which it is attributed and therefore an independent literary product in itself $)^{14}$, and a stable identifier to each colophon or scribal subscriptions. Coptic colophons provide valuable information, such as the names 
and professions of copyists - the latter often not working regularly as scribes -, places of copying, donors, etc., but they still need to be satisfactorily explored $^{15}$. As is well known, the CC classification has been initiated in the framework of the Corpus dei Manoscritti Copti Letterari (CMCL) ${ }^{16}$, but it needs to be expanded, updated, and disseminated, in order to become a completely reliable tool for standard use among specialists of late antique Egypt.

- A complete classification of the Coptic manuscript tradition, involving the attribution of stable identifiers to each manuscript (or rather, to each original "codicological unit"), ${ }^{17}$ in order to have univocal coordinates of reference to the entire Coptic book production. Such a classification is progressively expandable as new manuscripts are discovered. ${ }^{18}$

- A complete census of sites where individual manuscripts or entire "collections" have been found, visualizing them in historical maps. A tentative identification of places and geographical areas where specific works and literary genres have been conceived. As already said, such an attempt is particularly reasonable and sustainable for hagiographic and monastic literary production (for example, cycles of martyrdoms, encomia of monastic characters, etc.), where ideological and devotional motifs may be extremely telling. By means of internal elements, style and titles the project will try to anchor a corpus of works to a specific place or to a limited geographical area. ${ }^{19}$

- A complete archive of names of copyists, commissioners, donors, institutions and places involved in the production of manuscripts.

- A classification of the book formats, writing supports and other relevant codicological features of the manuscripts, in relation to the texts that they transmit.

\section{"PAThs" and the papyrus codices of the Museo Egizio}

P.B.

As part of the above-described research activities and goals, a complete catalogue of the Coptic papyrus codices preserved in the Museo Egizio will be produced. The fragmentary codices in question, purchased in Egypt by Bernardino Drovetti in the 1820 s, $^{20}$ are a unique example of an entire well-pre- served institutional late antique library - very likely originally belonging to the cathedral of Thi(ni)s, located not far from Abydos -, reflecting the literary tastes and dogmatic orientations before what can be defined as the ninth-century Coptic book revolution, which significantly changed bookmaking in Christian Egypt. ${ }^{21}$

We should not forget that in Egypt the shift from papyrus to parchment as a writing support was a technical innovation that directly affected the number of works transmitted by a single manuscript and sometimes even its contents. In this respect, the Thi(ni)s codices are the latest known example of an Egyptian library entirely transmitted by papyrus codices (probably datable between the end of the seventh century and the beginning of the eighth), and at the same time offer a rare occasion to study the criteria by which several literary works were assembled in one codex. It is interesting to note that only four out of these at least seventeen codices seem to be single-text manuscripts. What is even more important is that these single-text manuscripts do not transmit only biblical works, as happened in the past, but also other literary genres. This is the case of the Vita Epiphanii and, surprisingly, of a work of Shenoute (De iudicio supremo), a rare example of a work of the famous archimandrite transmitted outside the Shenoutean federation. All the other manuscripts are multiple-text codices containing from two to nine works and already present most of the physical elements that will characterize the last and better-known phase of Coptic books. The layout is normally in two columns, with few exceptions, and the titles always stand before the works they refer to, but only rarely mention a date. Subscriptiones (or final titles) occasionally survive, but no longer refer to the main titles. As regards their contents, the multiple-text codices of Turin show that Coptic culture was still evolving. There was a strong presence of Greek patristic works translated into Coptic in the fifth century (the so-called "classical translations", according to Tito Orlandi's classification), some apocrypha (such as the Acta Pilati), old-style works that reflect the theological controversies of the end of the fourth century (for instance, the Vita Aphou (Fig. 1), that was transmitted only by the Turin codex), some original works of the sixth century (such as Damian 
of Alexandria, De Nativitate), a few pseudepigraphal works - that is new works attributed to old or false authors - and a selection of normative works, such as the Gnomai Concilii Nicaeni. There is, however, no trace of classical or "pagan" works.

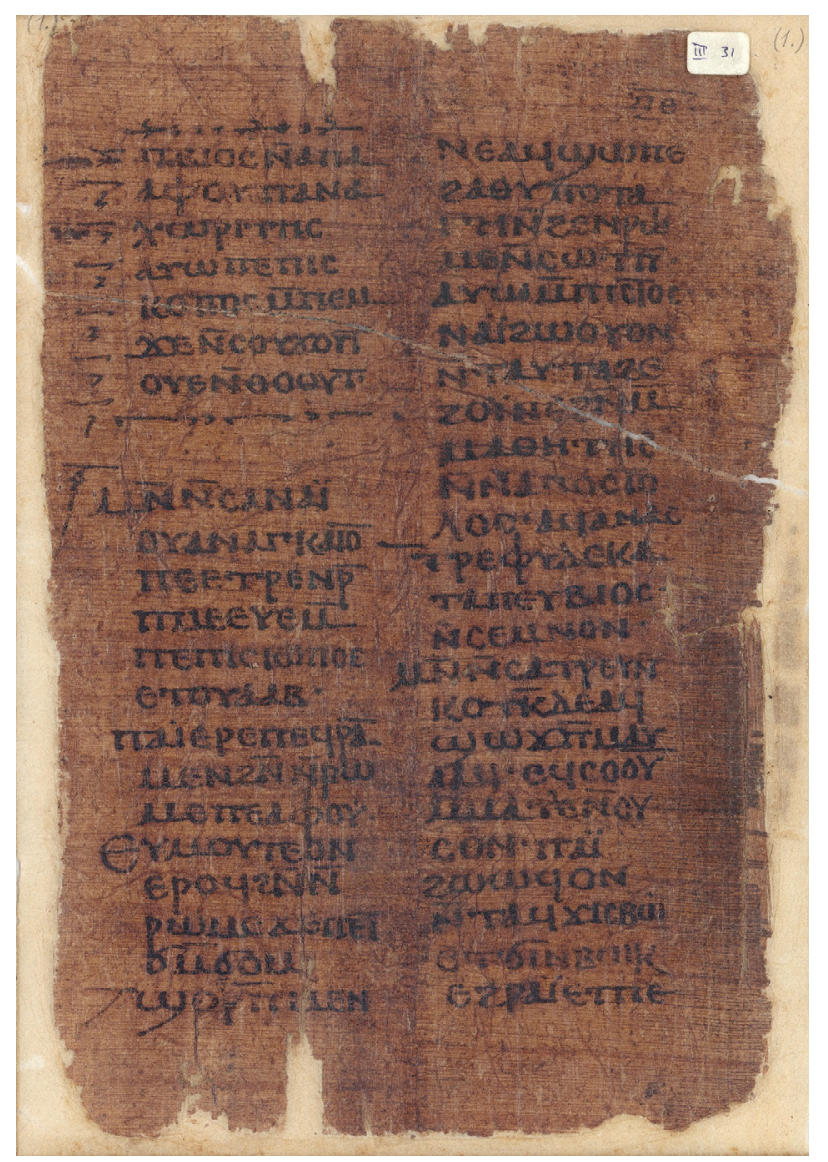

Fig. 1. Vita Aphou (Coptic Codex III), Turin Cat. 7120, sheet 31. Scanned image: Museo Egizio.

The codices that can be reconstructed with certainty are normally composed of quires of four bifolia (but Codex VI has surely irregular quires), the first four pages being normally blank. The pagination, when regular, is on each page, but there are interesting cases of irregular pagination. ${ }^{22}$ The first and last page of each quire bear a quire number.

In sum, the library of Thi(ni)s is a crucial and transitional instance in the history of Coptic books, which saw on the one hand the creation of new codicological and palaeographical features and on the other the progressive emergence of multiple-text codices. Our task will be to perform a structural analysis of these texts, and to define their history and the context in which they were produced, used and circulated.

\section{"PAThs" and the scribal subscriptions of the Coptic codices from Thi(ni)s}

A.S.

Among the aims pursued by "PAThs", as previously stated, are a complete census (as well as a concurrent attribution of a stable identifier number) and an edition, accompanied by an English translation, of all the extant Coptic colophons drafted between the third and the eleventh centuries.

The study of Coptic scribal subscriptions is a somewhat neglected domain, with the exception of van Lantschoot's sophisticated Recueil, where almost all the Sa'îdic colophons known up to the 1929 were masterfully (re-)edited, though without translation, and explained in a learned commentary. ${ }^{23}$ Rarely reaching the literary elaborateness that such paratexts often exhibit in other manuscript traditions of the Christian and Islamic Orient, the Coptic colophons, though bearing an annus Martyrum, have been usually exploited by scholars merely for manuscripts dating purposes. The exact dating of a manuscript, however, appears to be only a tangential detail compared to the host of information contained in them, whence PAThs' main outcome (the archaeological Atlas illustrating the geography and archaeology of Coptic literature) will tap its lifeblood.

Two papyri in the Museo Egizio of Turin are significant examples of the relevance of colophons as sources for historical geography, prosopography and social history. ${ }^{24}$ They may also provide an important clue about the origin of the papyrus codices mentioned above, as well as the origin of the copious unidentified fragments constituting the bulk of the Turin collection of Coptic literary manuscripts from Ğirğa, ancient Thi(ni)s. ${ }^{25}$

Ms. inv. no. Provv. 6266 (Fig. 2) is the almost fully preserved final page of a lost codex. ${ }^{26}$ It offers a terse scribal subscription informing us about the owner institution, the 'catholic church' of Thi(ni)s (1l.

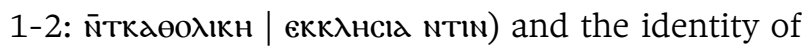
the copyist, the "humblest reader" (1. 4: педахістос nамагмостнс) Geōrgios. The blurry Greek chronological annotation does not much light on the date of the vanished codex: the $19^{\text {th }}$ day of Hathōr of a

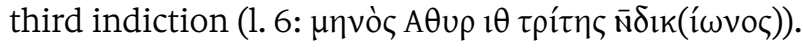
However, the few lines are followed by an accurate numbered list of the contents of the lost book 


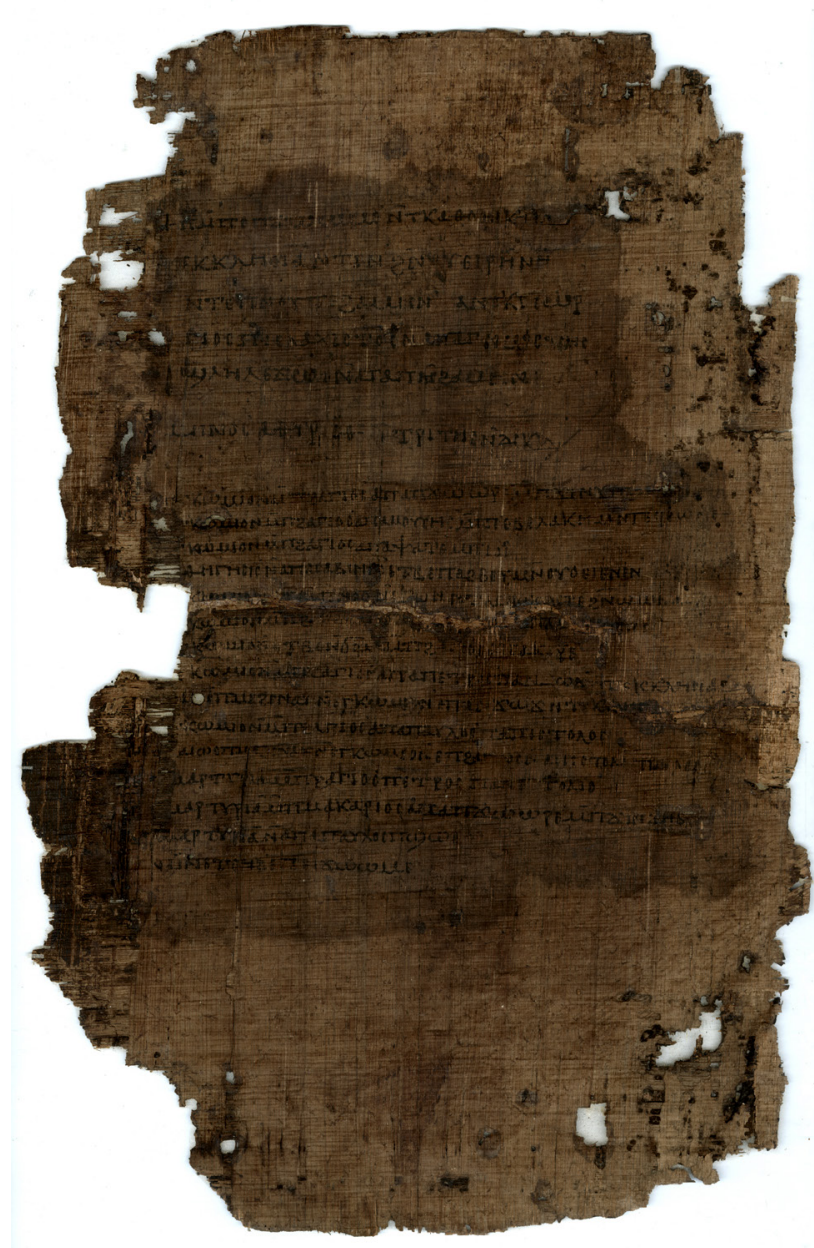

Fig. 2. Final sheet of a lost codex, Turin Provv. 6266. Scanned image: Museo Egizio.

(1. 21: маї метснг епєхоюме) by the same hand, albeit in smaller format.

An even more interesting text is preserved by Ms. Provv. 8548. ${ }^{27}$ This single leaf carries only the scribal subscription - a prayer on behalf of the donor of the manuscript -, which very likely concluded a codex; the remaining part is totally lost. It is written in a rather coarse hand and bears no date, but, as tentatively suggested by van Lantschoot, could be reasonably situated between the eighth and ninth centuries, or earlier. Both Christian Demut and faith in divine omniscience (1. 2: пхосыс ппотте сооүм जмeүрам) are the reason for the silence - also otherwise attested - about the name of the woman who bestowed the book (1. 1: па]ıє пернт м̄тамıм м'сqмe) to the monastery of St. John the Baptist in

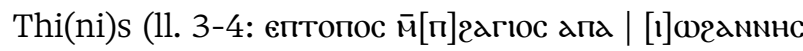
пваптістнс к̄Ṭוn). The name of her deceased hus-

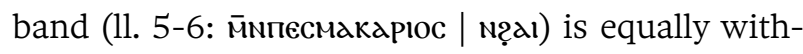
held, as are those of the other relatives for whom she was beseeching heavenly release. Eugène Revillout, the first scholar to deal with the document, informs us that it was originally en tête de la masse from which Codex III was recovered. He thus daringly supposed that the anonymous riche veuve égyptienne de Thébaïde, perhaps in fulfillment of a vow made by her departed spouse, bestowed the library (now kept in Turin) on the church and monastery of Alexandria consecrated to St. John the Baptist and founded by the patriarch Theophilus, which is sometimes mentioned in the literary works comprising the library. Van Lantschoot's correct reading of the slightly damaged toponym following the mention of the topos quoted in the note (1. 4: $\overline{\mathrm{N}}$ Ṭו $)$ allows us to trace the Turin codices to Thi(ni)s. ${ }^{28}$

\section{"PAThs" and Coptic hagiography}

M.C.G.

One of the main objectives of the "PAThs" project is to create an annotated catalogue of a number of literary texts that are particularly valuable because of their type, contents and chronology: this will allow us to demonstrate the complexity of Coptic literature and the diversity of the contexts in which these texts were produced, utilized, and circulated. tion of an analytical reading template specifically developed for the study of hagiographic texts, which will be recorded, dated, indexed and catalogued, taking advantage of the secondary bibliography at our disposal, most notably Tito Orlandi's works and all the information provided by the above-mentioned CMCL website. This template will shed light, mainly but not exclusively, on data related to Egyptian and non-Egyptian onomastic and toponomastic materials, to be compared with similar data obtained from titles and colophons.

A "qualitative survey" - that is, an observation of relevant topics and pivotal issues (devotional motifs, crucial historical moments, meaningful expressions, etc.) emerging from the reading when one is not looking for a specific answer - will enable users to collect other data that cannot be directly categorized in a template, but that might provide a basis for future projects and research.

Both of these operations - the application of a schematized reading template and the "qualitative 
survey" - will grant us deeper and more detailed knowledge of Coptic literature, its history (in terms of phases and literary genres), and its geography. ${ }^{29}$ One of the focuses of this work will be the monastic world, in order to shed light on the production and diffusion of specific texts. In this respect, another by-product of "PAThs" will be the study of the history of Egyptian monasticism.

The method employed is based on historical-critical analysis (reading, translating and comments on the text in its original language) and interdisciplinary approaches, particularly by connecting the products of archaeology to the study of sources (literature and documents, not only in Coptic but also in Greek, whenever they can contribute to a more complete reconstruction of a textual family). The aim of this part of the project is to transform the current patchwork of literary knowledge into a more coherent and comprehensive overview of Coptic literature, based upon comparison and interconnectivity.

- As for the creation of the archaeological Atlas of Coptic literature, this part of the work will be crucial for:

- mapping and localizing networks of places (monasteries, churches, basilicas, martyria) where texts were produced;

- analysing the dissemination and circulation of some specific texts;

- reconstructing the cultural and religious contexts of production and utilisation of literature, with special regard to social and economic peculiarities;

- studying the relationships between monasteries, secular families and social networks, with a focus on female roles.

The first case study we have chosen is the so-called "dossier of apa Claudius", composed of four encomia in honour of this martyr and attributed to different authors. This set of texts shows us how the Coptic minority organized itself and constructed its self-representation through a communication strategy borrowed from another minority, i.e., the martyrs on whom the violence organized by pagan imperial institutions was inflicted. This is allowing us to build a geography of sacred spaces based on the interconnection of monasteries, churches and mar- tyria. We will soon apply the same method to the literary works preserved in the Thi(ni)s codices.

\section{"PAThs" and the codicological aspects of Coptic books}

N.C.

The codicological finalities of the "PAThs" project are mainly two: 1) a complete census of Coptic literary manuscripts and 2) a codicological description of each manuscript. The census aims at listing the manuscripts in codex form, as well as the horizontal and vertical rolls (sometimes called rotuli) containing all the Coptic literary genres (with the exclusion of magical and liturgical texts). The census will also take into account literary ostraca (with the exception of biblical ones) when they are testimonies of the dissemination of Coptic literature.

Each manuscript - that is each ancient and original 'codicological unit' - will be provided with an identification number and a codicological description. The codicological description is founded on a protocol developed by the "PAThs" team, which records information about the manufacturing of the manuscript, its writing material (papyrus, parchment, paper) and its form.

In the case of codices, special attention will be given to the fashioning of the quires and their succession, and to the binding, when something of it survives. The dimensions of each page, of the writing frame and of the margins will be recorded, as well as the number of columns per page, the number of lines per column, and the number of letters per line, in order to provide detailed information about how the manuscript was assembled and written, and to identify groups of manuscripts sharing the same characteristics and possibly the same context of production and provenance. As stated above, in this perspective the papyrus Coptic literary manuscripts from Thi(ni)s, preserved in the Museo Egizio, are an especially special case study thanks to their excellent state of conservation and their known provenance.

\section{The digital archaeological Atlas of Coptic literature: its characteristics and its goals} J.B.

The archaeological Atlas of the Coptic literary manuscripts, the principal output of the "PAThs" project, 
will form a complex system whose kernel will be a series of relational online databases, which will be freely available for consultation, as well as for further implementation, and will make exclusive use of network technologies. All these resources will therefore be easily accessible and usable, thanks to multi-platform and largely available tools such as web browsers. This technological choice is aimed at abolishing any usage barrier and to lower, as much as possible, the learning curve both for experts and specialists - who, in close collaboration with one another, will increment the datasets with their research results and for the end users of the published material. Although the archaeological Atlas constitutes the main product of the project, the individual archives - the archive of Coptic literary manuscripts, of the places of book production, dissemination, and recovery, of the authors and their works, etc. - can be consulted independently. This is a key aspect, because an essential goal of the "PAThs" project is to become a touchstone in everything that concerns the production, dissemination, cataloguing, classification and study of Coptic literature.

The relational databases will be encompassed in customized geographical interfaces, capable of fully representing the complexity of the collected data in dynamic thematic maps and on different levels of analysis. Generic users will enjoy all the benefits of a well-organized system of "guided tours", presenting queries capable of guiding them through the complexity of scientific research and the results it has obtained. In addition to this, more granular research tools will be made available to specialists interested in making complicated custom queries and accessing deeper and more complex layers of information. A strict relational identification scheme of manuscripts, places, persons, literary genres, etc., will provide pinpointed links between all the entities considered. It will be possible, for example, to query the Atlas by simply clicking on a region or place - Thi(ni) $\mathrm{s}$, for instance - and obtain a full report on the manuscripts found there, sites of ancient manuscript production, the names of scribes active in that place at different periods, etc.

Special attention will be devoted to similar projects. Several international agreements have already been signed, and these collaborations will be further ex- panded, also in technical terms, in order to provide a free circulation of the linked data.

The whole information system will be developed using only open source software, libraries and protocols, in order to encourage the collaboration of external participants even in the earlier phases of development. We strongly believe that an open source and collaborative pattern of development will guarantee a longer lifespan to the information platform, since the durability and sustainability of software and protocols is an important issue in digital heritage projects.

\section{Further information concerning the "PAThs" project}

"PAThs - Tracking Papyrus and Parchment Paths: An Archaeological Atlas of Coptic Literature. Literary Texts in their Geographical Context. Production, Copying, Usage, Dissemination and Storage" - is an ERC Advanced project (2015 n687567) directed by Paola Buzi. It is based at Sapienza University of Rome (Italy).

The team is currently composed of Paola Buzi (Principal Investigator, Coptologist), Julian Bogdani (archaeologist and specialist of GIS and WebGIS and digital humanities applied to archaeology), Nathan Carlig (codicologist), Maria Chiara Giorda (historian), Agostino Soldati (philologist), Angela Bernardo (project coordinator with technical tasks), Angelo Colonna (Egyptologist), Ilaria Rossetti (Egyptologist), Francesco Berno (Historian of early Christianity), Francesco Valerio (philologist and codicologist) and Tea Ghigo (PnD candidate specialising in archaeometric analysis of inks).

Official address of the project:

"PAThs"

Dipartimento di Storia Culture Religioni

Sapienza Università di Roma

Piazzale Aldo Moro 5,

00185 Roma

paths.uniroma1.it

paola.buzi@uniroma1.it 


\section{Notes}

${ }^{1}$ Part of this section will also appear in Early Christianity 8 (2017), fasc. 4, pp. 3-12, forthcoming.

${ }^{2}$ Davis, The Early Coptic Papacy, pp. 2-14.

${ }^{3}$ Allen, The Ancient Egyptian Language, pp. 1-8.

${ }^{4}$ Orlandi, in Fiaccadori (ed.), Autori classici 93-104.

${ }^{5}$ Orlandi, in Dictionnaire de Spiritualité, XIV, coll. 797-804; Orlandi, in Nagel (ed.), Carl-Schmidt-Kolloquium pp. 129-142; Emmel, Shenoute's Literary Corpus.

${ }^{6}$ Simonetti, in Camplani (ed.), L'Egitto cristiano, pp. 11-38.

${ }^{7}$ Orlandi, in Siniscalco (ed.), Le antiche Chiese orientali, pp. 39-120.

${ }^{8}$ Delahaye, Annalecta Bollandiana 40 (1922), pp. 5-154, 299-364.

${ }^{9}$ Rubenson, Medieval Encounters 2.1 (1996), pp. 4-14; Papaconstantinou, Le Muséon 120 (2007), pp. 273-299.

${ }^{10}$ For the history of Coptic literature, see Orlandi, in Camplani (ed.), Egitto Cristiano, pp. 39-120 and Boud'hors, in Scott Fitzgerald (ed.), The Oxford Handbook, pp. 224-246.

${ }^{11}$ Petrucci, in Coco (ed.), La lettura spirituale, pp. 5-25; Crisci, in Muzerelle and Ornato (eds.), Il codice miscellaneo, pp. 109-144; Bagnall, Early Christian Books, pp 1-24.

${ }^{12}$ For a first systematic reflection on Coptic codicology, see Buzi and Emmel, Coptic Codicology, pp. 137-153.

${ }^{13}$ For more technical details about the archaeological Atlas, see the section by Julian Bogdani.

${ }^{14}$ Buzi, Titoli ed autori nella tradizione copta.

${ }^{15}$ On research aspects related to colophons, see the section by Agostino Soldati.

${ }^{16}$ http://www.cmcl.it/ (last access: November 2017).

${ }^{17}$ On the classification and codicological description of Coptic literary manuscripts, see the section by Nathan Carlig.

${ }^{18}$ This classification will take into consideration the results of previous and important projects, such as “Trismegistos" https://www.trismegistos.org/ (last access: January 2017), with which "PAThs" has already established a formal collaboration.

${ }^{19}$ On these aspects, see the section by Maria Chiara Giorda.

${ }^{20}$ Botti, Rendiconti dell'Accademia dei Lincei 30 (1921), pp. 128-315; Orlandi, Le Muséon 87 (1974), pp. 139151; Orlandi, Augustinianum53 (2013), pp. 501-530.

${ }^{21}$ Buzi, in Bausi et al. (eds.), The Emergence of Multiple-Text Manuscripts, pp. 93-110; Buzi, Egyptian \& Egyptological Documents5 (2015/2016) [2017], pp. 57-67.

${ }^{22}$ Buzi, in Bausi et al. (eds.), The Emergence of Multiple-Text Manuscripts, pp. 93-110; Buzi, Egyptian \& Egyptological Documents 5 (2015/2016) [2017], pp. 57-67.

${ }^{23}$ van Lantschoot, Recueil des colophons des manuscrits chrétiens d'Égypte; generally, on Coptic colophons see now Buzi, Emmel, Coptic Codicology, pp. 137-153 as well as Buzi, in Sirinian et al., Colofoni armeni a confronto, pp. 203-217.

${ }^{24}$ On the collection and the codices composing it, see above, n. 20.

${ }^{25}$ About this place see Timm, Das christlich-koptische Ägypten; see also Verreth, A Survey of Toponyms, p. $787 b$.

${ }^{26}$ Re-edited by van Lantschoot, Recueil des colophons, I.1, pp. 180-181, CV, commentary in I.2, pp. 72-73.

${ }^{27}$ First edition by Revillout, Journal Asiatique, S. VIII, I (1873), pp. 218-219; improved re-edition in van Lantschoot, Recueil des colophons, I.1, pp. 181-182, CVI, commentary in I.2, p. 74.

${ }^{28}$ See, at least, Orlandi, Les papyrus coptes, p. 116, as well as Orlandi, The Turin Coptic Papyri, p. 525.

${ }^{29}$ https://github.com/paths-erc/coptic-texts.

\section{Bibliography}

Allen, J.P., The Ancient Egyptian Language. An Historical Study, Cambridge 2013, pp. 1-8.

Bagnall, R.S., Early Christian Books in Egypt, Princeton 2009, pp 1-24.

Boud'hors, A., “The Coptic Tradition”, in J. Scott Fitzgerald (ed.), The Oxford Handbook of Late Antiquity, Oxford 2012, pp. 224-246.

Botti, G., "La collezione Drovetti e i papiri del R. Museo Egizio in Torino", Rendiconti dell'Accademia dei Lincei 30 (1921), pp. 128-315.

Buzi, P., Titoli ed autori nella tradizione copta: Studio storico e tipologico, Pisa 2005.

Buzi, P. "The Ninth-Century Coptic Book Revolution and the Emergence of Multiple-Text Manuscripts", in: A. Bausi, M. Maniaci and M. Friedrich (eds.), The Emergence of Multiple-Text Manuscripts, Berlin 2016, pp. 93-110.

Buzi, P., “Titoli e colofoni: riflessioni sugli elementi paratestuali dei manoscritti copti saidici”, in A. Sirinian, P. Buzi and G. Shurgaia, Colofoni armeni a confronto. Le sottoscrizioni dei manoscritti in ambito armeno e nelle altre tradizioni scrittorie del mondo mediterraneo. Atti del colloquio internazionale, Bologna, 12-13 ottobre 2012 (Orientalia Christiana Analecta, 299), Roma, Pontificio Istituto Orientale, 2016, pp. 203-217.

Buzi, P., "Amedeo Peyron and the Coptic Codices from This”, Egyptian \& Egyptological Documents, Archives, Libraries 5 (2015/2016) [2017], pp. 57-67.

Buzi, P. and S. Emmel, "Coptic Codicology”, in: A. Bausi et al. (eds.), Comparative Oriental Manuscript Studies: An Introduction, Hamburg 2015, pp. 137-153.

Crisci, E., "I più antichi codici miscellanei greci: materiali per una riflessione”, in: D. Muzerelle and E. Ornato (eds.), Il codice miscellaneo: tipologie e funzioni. Atti del Convegno Internazionale, Cassino 14-17 maggio 2003, Segno e Testo 2, (2004), pp. 109-144.

Davis, S., The Early Coptic Papacy: The Egyptian Church and Its Leadership in Late Antiquity, Cairo 2004, pp. 2-14.

Delahaye, H., "Les Martyrs d'Égypte”, Analecta Bollandiana 40 (1922), pp. 5-154, 299-364.

Emmel, S., Shenoute's Literary Corpus (CSCO 599-600, Subsidia 111-112), Louvain 2004.

van Lantschoot, A., Recueil des colophons des manuscrits chrétiens d'Égypte, I: Les colophons coptes des manuscrits sahidiques (Bibliothèque du Muséon, 1), Louvain 1929. 
Orlandi, T., "Les papyrus coptes du Musée Egyptien de Turin”, Le Muséon 87 (1974), pp. 139-151.

Orlandi, T., "Shenoute d'Atripé", in: Dictionnaire de Spiritualité, XIV, Paris 1989, coll. 797-804.

Orlandi, T., "Traduzioni dal greco al copto: quali e perché" in: G. Fiaccadori (ed.), Autori classici in lingue del Vicino e Medio Oriente, Roma 1990, pp. 93-104.

Orlandi, T., "Egyptian Monasticism and the Beginnings of the Coptic Literature", in: P. Nagel (ed.), Carl-Schmidt-Kolloquium an der Martin-Luther-Universität 1988, Halle 1990, pp. 129-142.

Orlandi, T., "Letteratura copta e cristianesimo nazionale egiziano”, in: A. Camplani (ed.), Egitto Cristiano: Aspetti e problemi in età tardo-antica, Roma 1997, pp. 39-120.

Orlandi, T., "La letteratura copta e la storia dell'Egitto cristiano”, in: P. Siniscalco (ed.), Le antiche Chiese orientali: Storia e letteratura, Roma 2005, pp. 85-117.

Orlandi, T., “The Turin Coptic Papyri”, Augustinianum 53 (2013), pp. 501-530.

Papaconstantinou, A., “'They Shall Speak the Arabic Language and Take Pride in It': Reconsidering the Fate of Coptic after the Arab Conquest", Le Muséon 120 (2007), pp. 273-299.

Petrucci, A., "Leggere nel Medioevo”, in: L. Coco (ed.),
La lettura spirituale: scrittori cristiani tra Medioevo ed età moderna, Milano 2005, pp. 5-25.

Revillout, E., "Le Concile de Nicée, d'après les textes coptes: Exposition de foi - Gnomes du Sainte Concile (papyrus du Musée de Turin)", Journal asiatique (S. VII), I (1873) pp. 210-288.

Rubenson, S., "Translating the Tradition: Some Remarks on the Arabization of the Patristic Heritage in Egypt", Medieval Encounters 2.1 (1996), pp. 4-14.

Simonetti, M., “Teologia e Cristologia nell’Egitto Cristiano", in: A. Camplani (ed.), L’Egitto cristiano: Aspetti e problemi in età tardo-antica, Roma 1997, pp. 11-38.

Timm, S. Das christlich-koptische Ägypten in arabischer Zeit: eine Sammlung christlicher Stätten in Ägypten in arabischer Zeit, unter Ausschluß von Alexandria, Kairo, des Apa-Mena-Klosters (Dēr Abū Mina), der Skētis (Wādi n-Națrūn) und der Sinai-Region, VI, Wiesbaden 1992, pp. 2682-2685.

Verreth, H., A Survey of Toponyms in Egypt in the Graeco-Roman Period (Trismegistos Online Publications 2, Vers. 2.0, http://www.trismegistos. org/top.php) Leuven 2013. 